\title{
Pheng Cheah, What Is a World? On Postcolonial
}

Literature as World Literature

\section{Christine Lorre-Johnston}

\section{(2) OpenEdition \\ 1 Journals}

Electronic version

URL: https://journals.openedition.org/ces/4673

DOI: $10.4000 /$ ces.4673

ISSN: 2534-6695

\section{Publisher}

SEPC (Société d'études des pays du Commonwealth)

\section{Printed version}

Date of publication: 1 April 2017

Number of pages: 121-122

ISSN: 2270-0633

\section{Electronic reference}

Christine Lorre-Johnston, "Pheng Cheah, What Is a World? On Postcolonial Literature as World Literature", Commonwealth Essays and Studies [Online], 39.2 | 2017, Online since 03 April 2021, connection on 04 June 2021. URL: http://journals.openedition.org/ces/4673 ; DOI: https://doi.org/10.4000/ces.4673

This text was automatically generated on 4 June 2021.

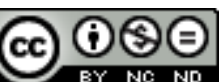

Commonwealth Essays and Studies is licensed under a Licence Creative Commons Attribution - Pas d'Utilisation Commerciale - Pas de Modification 4.0 International. 


\title{
Pheng Cheah, What Is a World? On Postcolonial Literature as World Literature
}

\author{
Christine Lorre-Johnston
}

\section{REFERENCES}

Pheng Cheah. What Is a World? On Postcolonial Literature as World Literature. Durham: Duke UP, 2016. 397 p. ISBN (pb): 978-0-8223-6092-6. US\$ 28.95

1 The definition of "world literature" has been subject to many discussions since the late $20^{\text {th }}$ century (see Cécile Girardin's review in this issue); with this book, Pheng Cheah adds a cogent contribution to it. He starts by asking the question "what is a world" when one talks of "world literature," challenging our spatial view of the world, as divided into time zones, when originally it was conceived as a temporal category. Conceptualizing the world in temporal terms, Cheah then undertakes to develop a "normative theory" of world literature, according to which literature can play a role in resisting and "transforming the world made by capitalist globalization" (2). In doing so, he also seeks to connect world literature and cosmopolitanism, understood as "viewing oneself as part of the world" (3), so that world literature's normativity is seen as "a modality of cosmopolitanism that responds to the need to remake the world as a place that is open to the emergence of peoples that globalisation deprives of world" (19).

2 In the first part of the book, "The World of World Literature in Question," Cheah goes back to philosophers' approaches to the world, mainly Hegel and Marx, to examine what we mean by "world" from the perspective of teleological time. Chapter 1 first looks at theory of world literature (David Damrosh, Pascale Casanova, Franco Moretti, and Goethe) and points at the need to distinguish between "world" meaning the globe, "the thing produced by processes of globalization" (42), and a form of belonging or relating that "opens up a new universal horizon" (41). Cheah also stresses the need to 
move away from the Eurocentrism of the tradition of Weltliteratur and comparative literature. In chapter 2, he examines some key ideas of Hegel's philosophy of world history, in which time is teleological and the world is a spiritual process marked by violence between the various nations and cultural forms. Chapter 3 moves on to Marx's materialist account of the world, in which literature has no worldly normative force. Yet, beyond the alienated world of the capitalist mode of production is the world to be created by "the teleological time of socialist revolution" (75).

3 The second part of the book, "Worlding and Unworlding: Worldliness, Narrative, and 'Literature' in Phenomenology and Deconstruction," examines phenomenological and deconstructive accounts of worldliness in relation to literature. It starts from the temporal concept of "worlding" (welten) coined by Heidegger, that is to say how a world is held together and given unity, to examine the normative force of world literature. Chapter 4 discusses further Heidegger's phenomenological account of the world. His ontological inquiry into modernity foregrounds alienation and worldlessness, but also the power of literature to disclose how temporality holds the world together and to open other worlds. Arendt's response to Heidegger is examined in chapter 5: she "anthropologizes" worlding, emphasizing human agency through natality and human activities, and considers story-telling as central to the worlding process, given the limited permanence of the material world. Chapter 6 is an analysis of Derrida's response to Heidegger. For Derrida, the world is not in the present of the relations between subjects, but is always arriving; it is in the event that is a "to-come" (l'à-venir). And it conveys messianic hope, because it cannot be totally appropriated by the imperatives of globalization. To Derrida, literature, because its meaning can never be fully determined, is exemplary of "the undecidability that opens a world" (180); it is "nothing other than the force of giving and receiving a world" (186).

Having thoroughly analysed the concept of worlding, Cheah proceeds to confront it with postcolonial literary works in the third part of his book, "Of Other Worlds to Come." He starts in chapter 7 by identifying inclusion/exclusion as a key aspect of the worlding process: how are human beings included in the world, what kind of whole is created, and what kind of temporality is adopted? Decolonization adopted a teleological view of time, through revolution, but that remained uncompleted. Current theories of alternative modernity and heterotemporality (Dipesh Chakrabarty, Nestor Garvia Canclini) propose paradigms that envision difference without reducing it to cultural difference. In the last three chapters, Cheah applies the questions he raised to studies of postcolonial narrative fiction, which "has become world literature by virtue of its participation in worlding processes" (213), against the background of globalization. His corpus includes works by Michele Cliff (dealing with Jamaica, slavery, and tourism; chapter 8); Amitav Ghosh (the Sudarban islands, the subaltern, and environmentalism; chapter 9); and Nuruddin Farah (Somalia, civil war, and humanitarianism; chapter 10) that are all set in places that were historically involved in trade with Europe, and then colonization. The epilogue, which studies works by Ninotchka Rosca and Timothy Mo (set in the Philippines), is closer to the temporality of American neo-colonialism.

5 Cheah's in-depth study of the philosophies of world, whose endpoint is always the role of literature in the worlding process, enables him to define a fresh take on world literature's normative function, in terms of inclusion/exclusion. His chosen corpus (except perhaps for the works in chapter 10) is in keeping with the "robust sense" of postcolonial world literature as activist literature (211), and he is able to demonstrate 
his point, even though the notion of cosmopolitanism, which is introduced in the first part, falls out of sight. The discussion of the philosophies of world is particularly valuable, and it would be interesting to explore further the concepts of world and worlding in relation to less activist, more poetic postcolonial literature.

\section{AUTHORS}

\section{CHRISTINE LORRE-JOHNSTON}

Christine LORRE-JOHNSTON is a Senior Lecturer in English at the Sorbonne Nouvelle. She coauthored (with Ailsa Cox) The Mind's Eye: Alice Munro's Dance of the Happy Shades (Fahrenheit, 2015), and co-edited (with Marta Dvorak) an issue of Commonwealth Essays and Studies on "Janet Frame: Short Fiction" (2011), (with Mireille Calle-Gruber and Sarah-Anaïs Crevier Goulet) Ecritures migrantes du genre: Croiser les théories et les formes littéraires dans les contextes comparés (Champion, 2017), and (with Eleonora Rao) A Book with Maps in It: Space and Place in Alice Munro's Short Stories (Camden House, forthcoming). 